\title{
PELATIHAN INTERNET DAN PENGENALAN E- COMMERCE BAGI MASYARAKAT DESA CIARUTEUN ILIR BOGOR
}

\author{
Abdul Haris ${ }^{1}$, Rahma Farah Ningrum ${ }^{2}$, Puji Catur Siswipraptini ${ }^{3}$, \\ Karina Djunaidi ${ }^{4}$, Rosida Nur Aziza ${ }^{5}$, Abdurrasyid ${ }^{6}$, Riki Ruli Siregar ${ }^{7}$ \\ 1,2,3,4,5,6,7 Sekolah Tinggi Teknik PLN \\ Program Studi Informatika \\ e-mail: ${ }^{1}$ harismkawang@sttpln.ac.id
}

\begin{abstract}
Abstrak
Ciaruteun Ilir adalah suatu desa di Kecamatan Cibungbulang di Kabupaten Bogor. Desa ini terletak sekitar 25 kilometer dari ibukota Kabupaten Bogor. Rata-rata masyarakatnya, yang sebagian besar bekerja di bidang pertanian, berada di garis kemiskinan dan memiliki tingkat pendidikan rendah. Fasilitas pendidikan formal masih sangat terbatas. Oleh karena itu, pelatihan dan kursus dari pemerintah maupun pihak-pihak lain diperlukan untuk meningkatkan pengetahuan, memperluas wawasan, dan meningkatkan keterampilan penduduk. Kursus-kursus yang diselenggarakan diharapkan dapat meningkatkan pendapatan warga desa. Sementara itu, wawasan yang lebih luas diharapkan dapat meningkatkan kesadaran warga akan pentingnya pendidikan. Tim PKM (Program Kemitraan Masyarakat) STT-PLN bermaksud untuk memberikan pelatihan terkait Teknologi Informasi kepada publik, khususnya mengenai pengenalan Internet. Selain itu, warga akan diberi pelatihan mengenai E-Commerce, yang merupakan salah satu aplikasi Internet yang memungkinkan transaksi jual beli melalui jaringan internet. Internet akan membuka peluang bagi warga untuk menambah pengetahuan dan belajar dari berbagai sumber. Dengan pelatihan E-Commerce, penduduk desa akan dilengkapi dengan kemampuan untuk dapat memperkenalkan produk dari desa mereka dan melakukan transaksi komersial melalui Internet.
\end{abstract}

Keywords : E-Commerce, Internet, PKM, Teknologi Informasi, Ciaruteun Ilir

\begin{abstract}
Ciaruteun Ilir is a village in the District of Cibungbulang, Bogor. It is located approximately 25 kilometres from the capital of the Bogor Regency. The average population, mostly farming, is on the poverty line and has a low level of education. Formal education facilities are still very limited. Therefore, training and courses from the government and other parties are needed to increase the knowledge, broaden their mind, and improve the skills of the population. The courses that are organized are expected to increase the villagers' income. While broader mind is expected to increase citizens' awareness of the importance of education. The PKM (Program Kemitraan Masyarakat or community service program) team intends to provide training related to Information Technology to the public, especially regarding the introduction of the
\end{abstract}


Internet. The public will be introduced to the Internet and E-Commerce, which is one of the Internet applications that allows buying and selling transactions through the Internet network. The internet will open opportunities for citizens to increase knowledge and learn from various sources. With E-Commerce training, villagers will be equipped with the ability to be able to introduce products from their villages and doing commercial transactions via the Internet.

Keywords : E-Commerce, Internet, PKM, Information Technology, Ciaruteun Ilir

\section{PENDAHULUAN}

Desa Ciaruteun Ilir, Kecamatan Cibungbulang, merupakan salah satu desa di Kabupaten Bogor, Jawa Barat. Desa Ciaruteun Ilir dengan kepadatan penduduk sebesar 29 per $\mathrm{km}$ ini memiliki jumlah penduduk sebesar 10.259 jiwa. Jumlah laki-laki di desa ini adalah 5.232 jiwa dan perempuan 5.027 jiwa dengan jumlah kepala keluarga sebesar 2.705 KK. Mayoritas masyarakat memiliki tingkat pendidikan terakhir Sekolah Menengah Pertama (SMP) . Jumlah penduduk yang berada pada usia 21-38 tahun menempati urutan terbanyak yaitu sebesar 996 untuk penduduk laki-laki dan 796 untuk penduduk perempuan. Pertanian merupakan sumber mata pencaharian utama di Desa Ciaruteun Ilir, terlihat dari besarnya luas lahan yang digunakan sebagai persawahan. Mayoritas penduduk di desa ini bermata pencaharian sebagai petani, baik sebagai petani pemilik lahan maupun sebagai buruh tani. Jumlah penduduk yang bekerja sebagai buruh tani menempati jumlah yang jauh lebih besar daripada penduduk yang bekerja sebagai petani pemilik lahan. Berdasarkan data monografi Desa Ciaruteun Ilir tahun 2011, diketahui bahwa lebih dari $90 \%$ warga desa bekerja di sektor pertanian [1].

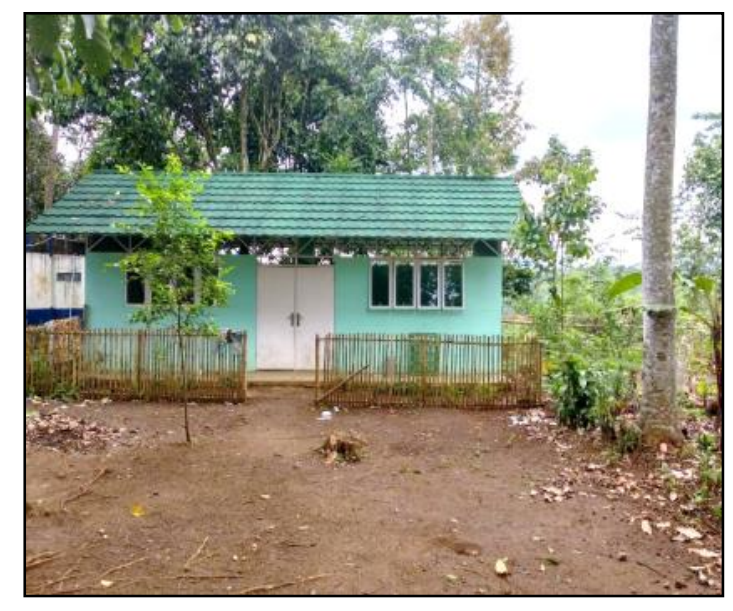

Gambar 1. Rumah Belajar milik Yayasan Desa Mandiri, Ciaruteun Ilir

Pada beberapa bagian Desa Ciaruteun Ilir, misalnya di Kampung Poncol, banyak warga desa belum mengenyam bangku sekolah karena terkendala minimnya fasilitas 
pendidikan, mahalnya biaya sekolah dan jarak ke sekolah yang cukup jauh . Banyak orang tua yang menyuruh anak-anak mereka untuk membantu di ladang dibandingkan duduk di bangku sekolah. Di kampung tersebut, terdapat komunitas belajar yang dibentuk oleh sekelompok masyarakat. Tetapi komunitas belajar tersebut tidak memiliki fasilitas yang memadai dan tenaga pengajar yang cukup. Tempat belajar komunitas tersebut ditunjukkan pada gambar 1. Tenaga pengajar hanya berasal dari relawan ataupun masyarakat sekitar yang jumlahnya masih sangat kurang jika dibandingkan dengan jumlah anak dengan rentang umur 6-12 tahun yang sangat membutuhkan pendidikan.

Perkembangan teknologi informasi, khusunya internet, saat ini sangat pesat. Internet menyebabkan pengguna-penggunanya untuk merubah kebiasaan lama mereka ke arah yang lebih inovatif . Internet dan teknologi digital secara keseluruhan merevolusi cara manusia dalam memberikan pendidikan baik, formal maupun informal, berinteraksi dengan masyarakat, melakukan proses belajar- mengajar dan bekerja, serta berbagai hal lain dalam aktivitas sehari-hari. Internet menawarkan berbagai kesempatan bagi penggunanya untuk belajar, bertukar pengetahuan, dan berkembang ke arah yang lebih baik. Internet telah menyebabkan banyak perubahan di dalam komunitas [2]. Di Indonesia, penggunaan internet juga sudah meluas ke daerah pinggiran dan kota-kota kecil di Indonesia, seperti yang dilaporkan dalam hasil penelitian dari Ekasari dan Dharmawan [3]. Berdasarkan hasil survey dari suatu lembaga riset pasar Internasional yang dilansir oleh situs Kementerian Komunikasi dan Informatika Republik Indonesia, jumlah pengguna Internet di Indonesia tahun 2017 mencapai 143,26 juta jiwa atau setara dengan 54,68\% dari total jumlah penduduk. Dari jumlah pengguna Internet tersebut, $74,62 \%$ berasal dari kalangan menengah ke bawah[4]. Hal ini menunjukkan bahwa penggunaan Internet di Indonesia telah menjangkau berbagai lapisan masyarakat. Bahkan Internet dipandang sebagai solusi untuk mengatasi masalah komunikasi di daerah atau desa yang jauh dari perkotaan, seperti pada kasus di Desa Nyamuk, Kecamatan Karimunjawa, Jepara [5].

Salah satu aplikasi dari Internet adalah e-commerce, yang merupakan kepanjangan dari electronic commerce. Definisi dari e-commerce ini adalah proses membeli dan menjual produk-produk secara elektronik oleh konsumen dan dari perusahaan ke perusahaan dengan komputer sebagai perantara transaksi bisnis [6]. Atau kegiatan penjualan, pembelian, dan pemasaran barang serta jasa melalui sistem elektronik, seperti internet, televisi atau jaringan komputer lainnya. E-commerce memungkinkan penggunapengguna Internet, baik pribadi maupun perusahaan, melaksanakan kegiatan bisnis dengan cara yang lebih efisien. Penjual dan pembeli tidak harus bertemu di suatu tempat, toko atau pasar, untuk mengadakan transaksi. Transaksi tidak harus dilaksanakan dengan pembayaran uang secara langsung, tetapi cukup melalui pemindahan dana antar rekening. Kemudahan dan kepraktisan $e$-commerce menyebabkan e-commerce berkembang cepat di masyarakat. Menurut penelitian Padmannavar [7], dengan adanya e-commerce banyak wanita-wanita pengusaha di negara Padmannavar, 2011 berkembang yang terbantu dalam 
menawarkan barang dan jasa, menemukan pasar baru, memperoleh order-order baru, dan pengurangan biaya dalam pelaksanaan transaksi bisnis.

Berdasarkan latar belakang tersebut, Tim PKM STT PLN bermaksud mengadakan kegiatan pengenalan dan pelatihan Internet dan E-Commerce bagi tenaga pengajar komunitas belajar Kampung Poncol dan masyarakat Desa Ciaruteun Ilir. Dengan pelatihan tersebut, warga diharapkan memiliki tambahan wawasan dan modal ketrampilan untuk lebih meningkatkan pendapatan dan taraf hidup mereka.

\section{METODE}

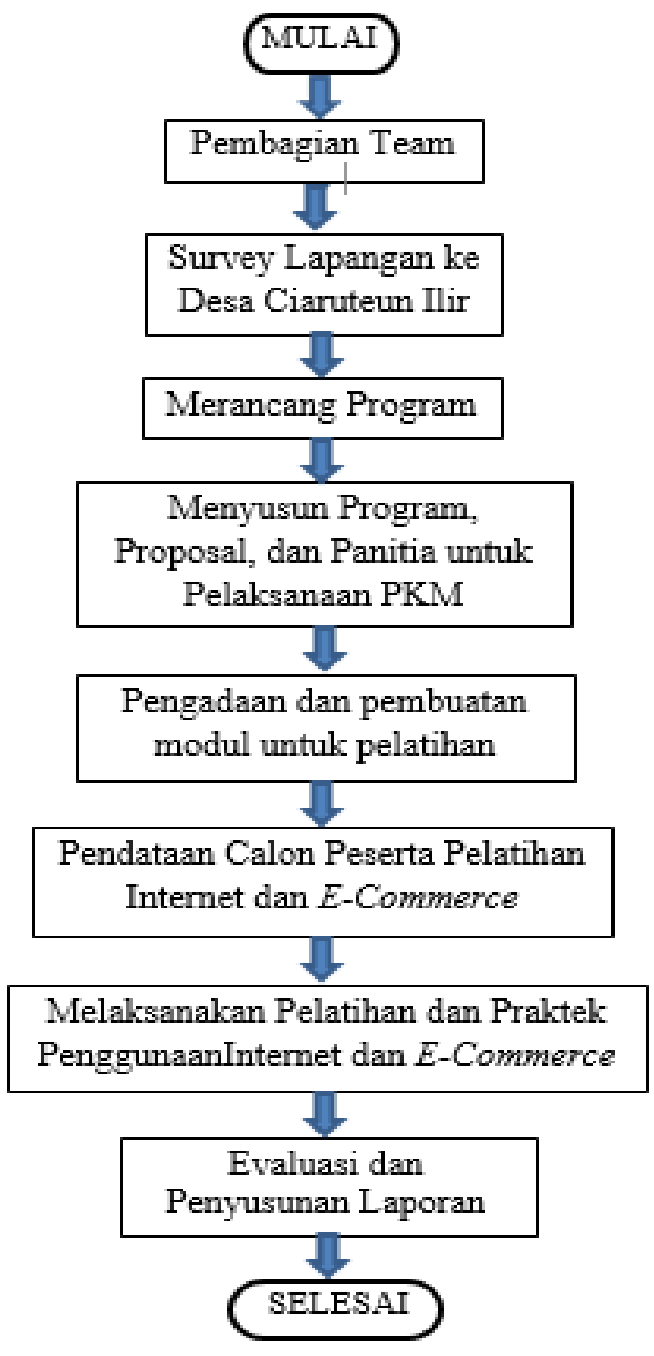

Gambar 2. Metode Pelaksanaan PKM STT PLN di Ciaruteun Ilir 
Gambar 2 di atas menunjukkan tahapan pelaksanaan kegiatan Program Kemitraan Masyarakat (PKM) di Desa Ciaruteun Ilir, Kecamatan Cibungbulan, Bogor. Kegiatan diawali dengan pembentukan tim PKM dan penentuan lokasi yang menjadi sasaran PKM. Pencarian lokasi dilaksanakan oleh tim PKM yang terdiri dari dosen dan beberapa mahasiswa Teknik Informatikan STT PLN. Tahapan selanjutnya adalah melakukan survey ke lokasi untuk mengetahui kondisi lokasi dan keadaan masyarakat setempat. Pelaksanaan survey dilakukan lebih dari sekali dan diikuti dengan wawancara terhadap tokoh setempat untuk menggali kebutuhan warga desa. Selain apparat setempat, tim juga bekerja sama dengan kelompok belajar Yayasan Desa Mentari.

Berdasarkan survey dan wawancara dengan pihak pamong Desa Ciaruteun Ilir dan Ketua Yayasan, dapat disimpulkan beberapa masalah yang dihadapi warga, antara lain :

1. Bagaimana membantu masyarakat dalam mendukung infrastruktur pendidikan pada komunitas belajar yang telah ada?

2. Bagaimana membantu masyarakat untuk meningkatkan taraf hidup yang sesuai dengan kondisi pekerjaan masyarakat dengan memberikan pendampingan dan pelatihan?

3. Bagaimana memperkenalkan teknologi informasi sebagai media bantu dalam memasarkan hasil panen yang mayoritas penduduk adalah petani?

4. Bagaimana mengubah pemikiran masyarakat yang lebih mengutamakan ekonomi dibandingkan Pendidikan?

5. Bagaimana memperbaiki gaya hidup masyarakat ke arah yang lebih baik dengan Pendidikan dan pelatihan?

Dalam rangka menyelesaikan permasalahan yang terkait dengan masih kurangnya tingkat pendidikan masyarakat, rancangan solusi yang ditawarkan adalah :

a) Membuat sosialisasi mengenai penggunaan Internet yang bijaksana.

b) Melakukan sosialisasi mengenai pemanfaatan Internet untuk menambah wawasan dan pengetahuan.

c) Melakukan pelatihan dasar mengenai penggunaan E-Commerce untuk membantu memperluas wilayah pemasaran hasil pertanian warga Desa Ciaruteun Ilir dan membantu menjual hasil pertanian warga melalui Internet.

d) Untuk meningkatkan infrastruktur sarana belajar, tim PKM STT PLN juga membantu perbaikan kamar mandi dan penambahan pintu kamar mandi di bangunan milik kelompok belajar Yayasan Desa Mandiri di desa tersebut.

Pelaksanaan pelatihan Internet dan pengenalan E-Commerce ini akan dilaksanakan dalam 2 sesi dengan target jumlah peserta adalah 30 orang. Kegiatan ini diselenggarakan dalam 2 hari ( 1 hari untuk pelatihan dan 1 hari untuk perbaikan sarana prasarana). Setiap peserta akan diberi modul pelatihan dan diberi kesempatan untuk praktek langsung menggunakan komputer yang disediakan panitia atau telepon genggam pintar (smart 
phone) yang dimiliki warga. Adapun langkah-langkah pelaksanaan pelatihan adalah sebagai berikut :

Langkah 1 : Peserta diberi penjelasan mengenai pengertian Internet, berbagai fasilitas yang ditawarkan Internet, dan penggunaan Internet secara bijaksana.

Langkah 2 : Peserta diberi penjelasan mengenai penggunaan Internet secara umum dan bagaimana mengakses lokasi Situs yang ingin dituju.

Langkah 3 : Peserta diberi kesempatan untuk mencoba mengakses Internet melalui komputer atau telepon genggam.

Langkah 4 : Peserta dijelaskan mengenai cara melakukan kegiatan ekonomi, seperti : jual, beli, dan promosi, melalui Internet.

Langkah 5 : Peserta akan diberikan tugas sesuai dengan materi yang telah disampaikan.

Langkah 6 : Kerja bakti antara tim PKM STT PLN dengan warga untuk membersihkan dan memperbaiki gedung sarana belajar miliki Yayasan Desa Mandiri berupa pemasangan pintu kamar mandi.

Adapun tim PKM yang akan melaksanakan kegiatan pelatihan ini ditunjukkan pada Tabel 1, sebagai berikut :

Tabel 1. Anggota Tim PKM

\begin{tabular}{|l|l|}
\hline Nama & Uraian Tugas \\
\hline $\begin{array}{l}\text { Abdul Haris S.Kom., } \\
\text { M.Kom./0315038204 }\end{array}$ & $\begin{array}{l}\text { Mengkoordinir } \\
\text { pelaksanaan kegiatan }\end{array}$ \\
\hline $\begin{array}{l}\text { Rosida Nur Aziza, ST, } \\
\text { M.Eng.Stud. / } \\
\text { 0328127305 }\end{array}$ & $\begin{array}{l}\text { Menyusun proposal } \\
\text { dan laporan } \\
\text { pertanggungjawaban }\end{array}$ \\
\hline $\begin{array}{l}\text { Karina Djunaidi, ST., } \\
\text { M.TI./ 0313058902 }\end{array}$ & Bendahara \\
\hline $\begin{array}{l}\text { Puji Catur Siswiprap-tini, } \\
\text { ST., M.TI / } \\
\text { 0301027703 }\end{array}$ & $\begin{array}{l}\text { Penyusun modul } \\
\text { untuk pelatihan }\end{array}$ \\
\hline $\begin{array}{l}\text { Rahma Farah Ningrum, } \\
\text { S.Kom., } \\
\text { M.Kom./0415078201 }\end{array}$ & $\begin{array}{l}\text { Penyusun modul } \\
\text { untuk pelatihan }\end{array}$ \\
\hline $\begin{array}{l}\text { Riki Ruli Siregar, } \\
\text { S.Kom., M.Kom. / } \\
\text { 0301057706 }\end{array}$ & $\begin{array}{l}\text { Memberikan materi } \\
\text { pelatihan }\end{array}$ \\
\hline $\begin{array}{l}\text { Abdurrasyid,S.Kom., } \\
\text { MMSI./0310068702 }\end{array}$ & $\begin{array}{l}\text { Memberikan materi } \\
\text { pelatihan }\end{array}$ \\
\hline
\end{tabular}




\section{HASIL DAN PEMBAHASAN}

Hasil dari pelaksanaan PKM (Program Kemitraan Masyarakat ) Tim PKM STT PLN di Desa Ciaruteun Ilir, Bogor, berupa 2 kegiatan, yaitu : pelatihan E-Commerce untuk warga desa dan perbaikan sarana belajar desa milik Yayasan Desa Mentari. Kegiatan pertama berupa Pelatihan E-Commerce yang diikuti oleh pengajar Yayasan Desa Mentari dan warga Desa Ciaruteun Ilir, sebanyak 35 peserta. Gambar 3 menunjukkan anggota tim PKM dari Departemen Informatika yang melaksanakan pelatihan. Pada awal pelatihan tersebut, peserta diberi informasi mengenai STT PLN, disusul dengan penjelasan mengenai pentingnya menambah wawasan dan ilmu melalui bangku pendidikan,. Penjelasan tersebut diberikan supaya orang tua-orang tua di Ciaruteun Ilir lebih memperhatikan pendidikan putra-putri mereka. Selanjutnya, pemberi materi menjelaskan mengensi kegunaan Internet untuk melaksanakan kegiatan ekonomi melalui beberapa situs jual beli yang sudah ada. Cara membuat email dan membuka akun, kemudian langkah-langkah melakukan pembelian, serta penjualan melalui Internet juga dibahas pada pelatihan tersebut.

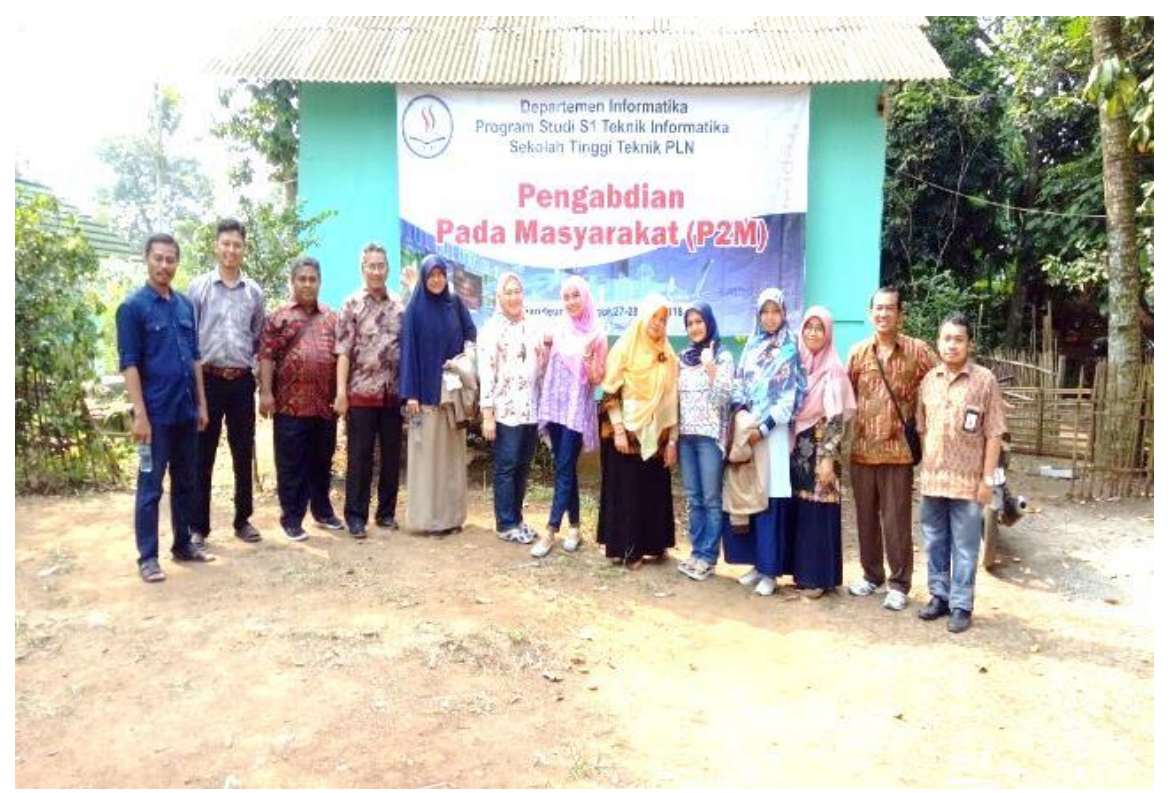

Gambar 3. Tim PKM STT PLN

Gambar 4 dan 5 menunjukkan suasana ketika pelatihan. Pelatihan yang disampaikan secara interaktif menggunakan komputer dan proyektor tersebut disampaikan oleh Bapak Abdul Haris dan Bapak Abdurrasyid. Pada gambar 5 terlihat Bapak Abdurrasyid sedang menjelaskan materi kedua mengenai penggunaan $e$-commerce. 


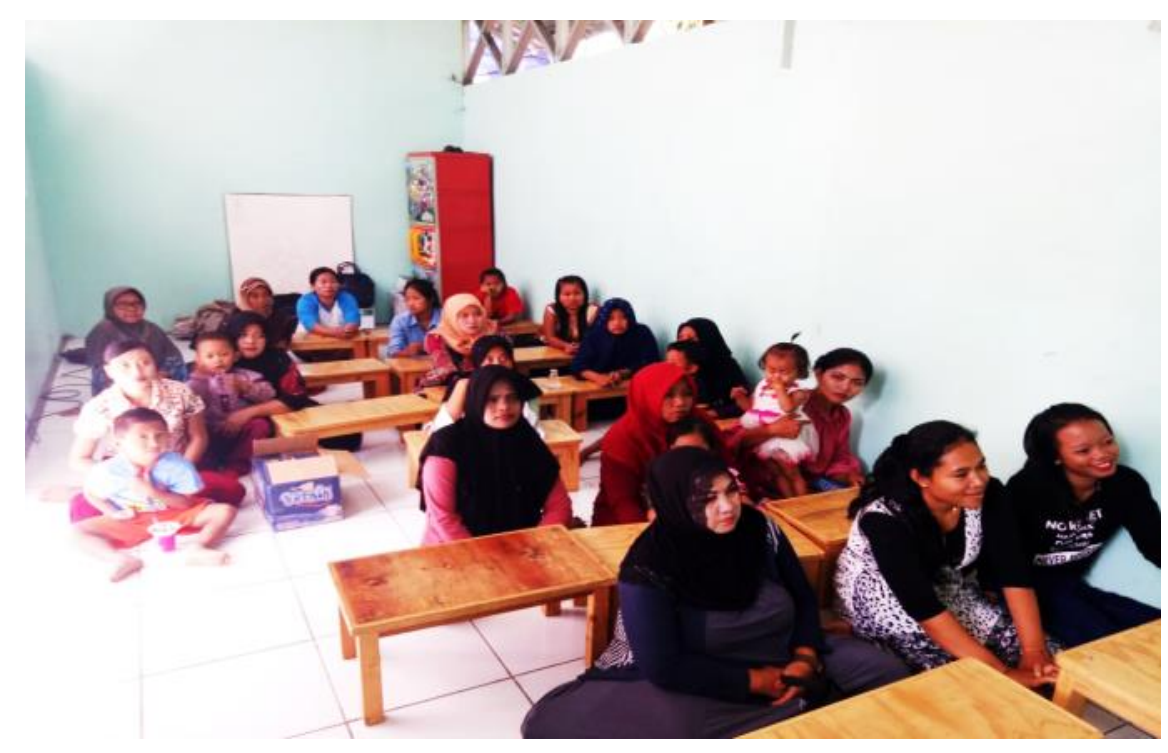

Gambar 4. Peserta pelatihan e-commerce

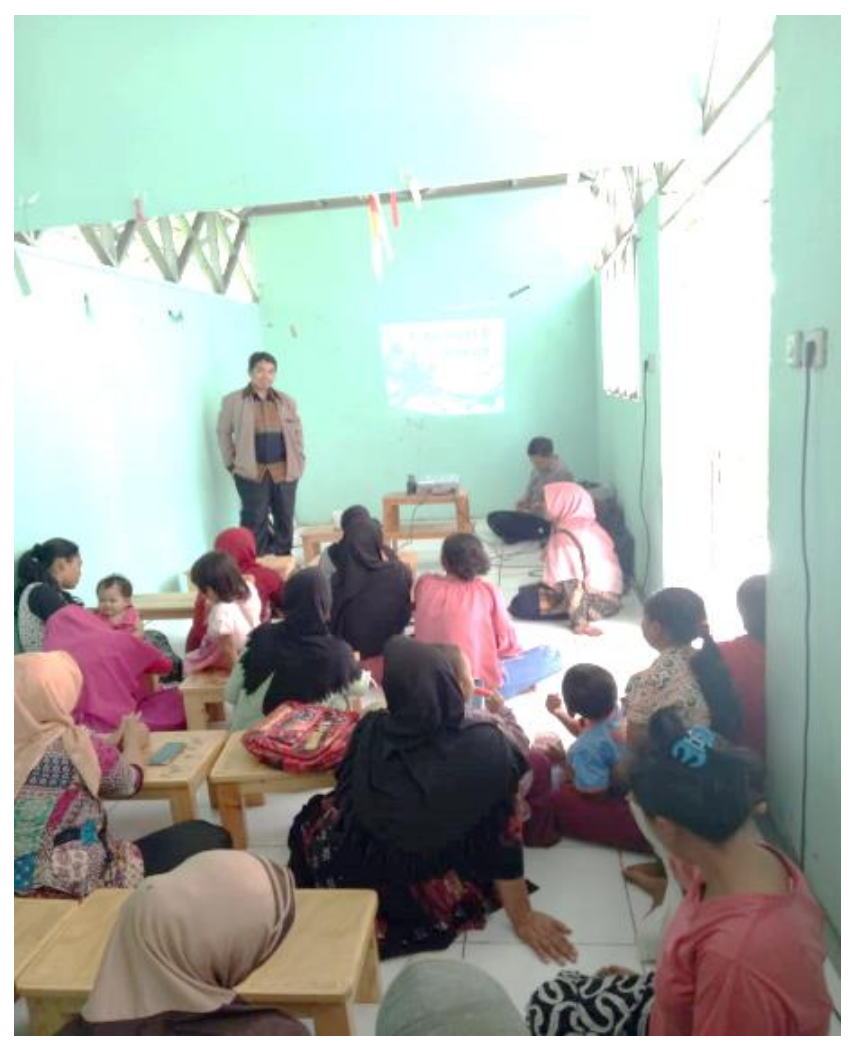

Gambar 5. Suasana kegiatan pengenalan Internet dan pelatihan E-Commerce 


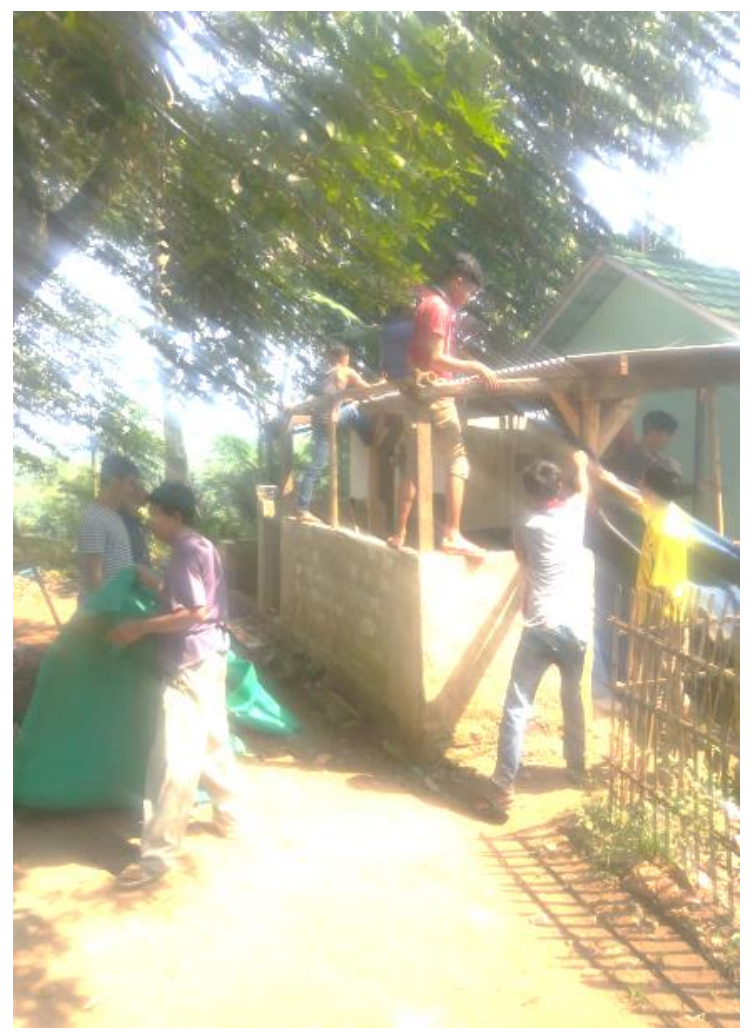

Gambar 6. Kegiatan perbaikan sarana gedung belajar Yayasan Desa Mentari

Kegiatan kedua berupa gotong royong anatara tim PKM STT PLN dengan masyarakat setempat untuk memperbaiki gedung tempat belajar milik Yayasan Desa Mentari. Bagian yang diperbaiki antara lain adalah atap dan pintu kamar mandi gedung tersebut. Gambar 6 di atas menggambarkan kegiatan gotong royong warga desa dengan tim PKM STT PLN sedang memasang atap baru di bagian belakang gedung belajar tersebut.

Kerjasama antara Tim PKM STT PLN dengan masyarakat Desa Ciaruteun Ilir, Kecamatan Cibungbulang, Bogor menghasilkan kegiatan pengenalan dan pelatihan $E$ Commerce untuk menambah wawasan masyarakat dan ketrampilan masyarakat untuk melakukan jual beli melalui internet. Penambahan wawasan tersebut diharapkan meningkatkan kesadaran akan pentingnya pendidikan. Kemampuan melakukan kegiatan jual beli melalui Internet diharapkan mampu menjadi alternatif untuk menambah pemasukan keluarga. Dengan kata lain, keluaran dari kegiatan ini adalah :

1. Pelatihan dasar E-Commerce bagi warga Desa Ciaruteun Ilir

2. Modul pelatihan dasar E-Commerce

3. Kerja bakti Tim PKM dengan warga untuk memperbaiki fasilitas gedung belajar milik Yayasa Desa Mentari. 
Dari peserta yang hadir, beberapa memiliki telepon genggam pintar dan telah mampu menggunakannya untuk komunikasi dan kegiatan browsing. Namun, berdasarkan pengamatan, sebagian besar peserta belum mengerti perlunya membuka akun untuk melakukan kegiatan e-commerce. Jadi cara membuat email dan akun di aplikasi $e$ commerce juga dijelaskan kepada peserta oleh tim PKM.

\section{KESIMPULAN}

Pelaksanaan kegiatan Program Kemitraan Masyarakat (PKM) antara Tim PKM STT PLN dengan masyarakat Desa Ciaruteun Ilir, Kecamatan Cibungbulang, Bogor menghasilkan kegiatan pengenalan dan pelatihan E-Commerce untuk menambah wawasan masyarakat dan ketrampilan masyarakat untuk melakukan jual beli melalui internet. Penambahan wawasan tersebut diharapkan meningkatkan kesadaran akan pentingnya pendidikan. Kemampuan melakukan kegiatan jual beli melalui Internet diharapkan mampu menjadi alternatif untuk menambah pemasukan keluarga. Selain kegiatan pelatihan, Tim PKM juga bergotong royong dengan masyarakat memperbaiki gedung milik Yayasan Mentari yang biasa digunakan untuk kegiatan belajar mengajar.

Faktor-faktor penghambat dalam pelaksanaan kegiatan ini antara lain lokasi yang jauh dan tidak dapat dijangkau oleh kendaraan roda 4 sehingga tim PKM memerlukan waktu untuk mencapai lokasi dan membawa perlengkapan yang diperlukan. Lokasi yang terpencil menyebabkan penerimaan sinyal telepon yang kurang baik sehingga peserta perlu waktu lebih lama untuk mengakses situs-situs yang diperlukan selama pelatihan. Waktu pelaksanaan pelatihan di hari Jum'at menyebabkan waktu pelaksanaan pelatihan tidak terlalu optimal karena waktu istirahat yang cukup lama untuk sholat Jum'at dan makan siang.

\section{SARAN}

Karena banyak warga yang tidak mengenyam bangku pendidikan sampai SMA, maka diperlukan pelatihan-pelatihan untuk menambah pengetahuan dan ketrampilan warga terutama warga dengan usia produktif. Pelatihan yang diberikan oleh tim PKM STT PLN masih sederhana dan perlu ditindaklanjuti dengan pelatihan-pelatihan lain yang lebih mendalam.

Jumlah perempuan yang menikah dan telah menjadi ibu pada usia belia juga cukup banyak. Pelatihan yang khusus ditujukan untuk menambah ketrampilan ibu-ibu muda tersebut juga perlu diberikan supaya ibu-ibu tersebut dapat berkarya dan mendapat tambahan penghasilan untuk keluarga. 


\section{UCAPAN TERIMA KASIH}

Penulis mengucapkan terima kasih kepada STT-PLN, Yayasan Desa Mentari, dan Aparat Desa Ciaruteun Ilir, Kabupaten Bogor, yang telah memberikan dukungan dan bantuan sehingga pelaksanaan kegiatan program kemitraan masyarakat ini dapat terselenggara dengan lancar.

\section{DAFTAR PUSTAKA}

[1] Firda, P.B.H., _ , Profil Desa Ciaruteun Ilir, Kecamatan Cibungbulang, Kabupaten Bogor, repository.ipb.ac.id.

[2] Haythornhwaite,C. dan Kendall, L., 2010, Internet and Community, American Behavioral Scientist, Volume 53, Issue $8: 1083$ - 1094.

[3] Ekasari, P., dan A.H. Dharmawan, Socio Economic Impacts by the Internet Usage in Villages, Sodality : Jurnal Sosiologi Pedesaan, Vol. 06, No. 01, April 2012.

[4] Biro Humas Kementrian KOMINFO, 2018, Jumlah Pengguna Internet 2017 Meningkat, Kominfo Terus Lakukan Percepatan Pembangunan Broadband, Siaran PERS No. 53/HM/KOMINFO/02/2018, kominfo.go.id.

[5] Sumbodo, B.A.A., A.Dharmawan, dan Faizah, 2017, Implementasi Teknologi Internet sebagai Solusi Pengentasan Masalah Komunikasi di Desa Nyamuk Kecamatan Karimunjawa Kabupaten Jepara, Jurnal Pengabdian Kepada Masyarakat , Volume 2, Nomor 2.

[6] Loudon, K.C dan Carol G.Traver, 2007, E-Commerce, Pearson, New Jersey.

[7] Padmannavar, S.S., A Review on E-Commerce Empowering Women, International Journal of Computer Science and Telecommunications, Volume 2 , Issue 8, November 2011. 